IZA DP No. 5144

Micro-Level Determinants of Lecture Attendance and Additional Study-Hours

Martin Ryan

Liam Delaney

Colm Harmon

August 2010 


\title{
Micro-Level Determinants of Lecture Attendance and Additional Study-Hours
}

\author{
Martin Ryan \\ University College Dublin \\ Liam Delaney \\ University College Dublin \\ Colm Harmon \\ University College Dublin \\ and IZA
}

\author{
Discussion Paper No. 5144 \\ August 2010
}

IZA
P.O. Box 7240
53072 Bonn
Germany

Phone: +49-228-3894-0

Fax: +49-228-3894-180

E-mail: iza@iza.org

\begin{abstract}
Any opinions expressed here are those of the author(s) and not those of IZA. Research published in this series may include views on policy, but the institute itself takes no institutional policy positions.

The Institute for the Study of Labor (IZA) in Bonn is a local and virtual international research center and a place of communication between science, politics and business. IZA is an independent nonprofit organization supported by Deutsche Post Foundation. The center is associated with the University of Bonn and offers a stimulating research environment through its international network, workshops and conferences, data service, project support, research visits and doctoral program. IZA engages in (i) original and internationally competitive research in all fields of labor economics, (ii) development of policy concepts, and (iii) dissemination of research results and concepts to the interested public.
\end{abstract}

IZA Discussion Papers often represent preliminary work and are circulated to encourage discussion. Citation of such a paper should account for its provisional character. A revised version may be available directly from the author. 


\section{ABSTRACT \\ Micro-Level Determinants of Lecture Attendance and Additional Study-Hours ${ }^{*}$}

This paper uses novel measures of individual differences that produce new insights about student inputs into the (higher) education production function. The inputs examined are lecture attendance and additional study-hours. The data were collected through a web-survey that the authors designed. The analysis includes novel measures of individual differences including willingness to take risks, consideration of future consequences and non-cognitive ability traits. Besides age, gender and year of study, the main determinants of lecture attendance and additional study-hours are attitude to risk, future-orientation and conscientiousness. In addition, future-orientation, and in particular conscientiousness, determine lecture attendance to a greater extent than they determine additional study. Finally, we show that family income and financial transfers (from both parents and the state) do not determine any educational input. This study suggests that non-cognitive abilities may be more important than financial constraints in the determination of inputs related to educational production functions.

JEL Classification: $\quad 121, \mathrm{~J} 2, \mathrm{D} 90$

Keywords: $\quad$ higher education, education inputs, lecture attendance, hours of study, future-orientation, attitude to risk, non-cognitive ability, conscientiousness

Corresponding author:

Martin Ryan

Geary Institute

University College Dublin

Belfield, Dublin 4

Ireland

E-mail: martin.ryan@ucd.ie

\footnotetext{
* Thanks to seminar participants at the UCD School of Economics and the Geary Institute for providing comments; and to conference participants at the annual conference of the Irish Economics Association (Bunclody; April 2008), at "What's The Behavioural in Behavioural Economics?" in Trento (June 2008), at the annual conference of the International Association for Research in Economics and Psychology (Rome; September 2008), at the Economics and Psychology One-Day Event at NUI Maynooth (November 2008), at the International Workshop on the Applied Economics of Education (Catanzaro; June 2010) and at the XIX Meeting of the Economics of Education Association (Zaragoza; July 2010). Particular thanks to Kevin Denny for comments. Thanks to Richard Williams for help with a technical query. Thanks to Michael Egan for help with document preparation and proofing. The corresponding author acknowledges financial support from the Irish Research Council for the Humanities and Social Sciences
} 


\section{Introduction}

A simple production model lies behind much of the analysis in the economics of education. The common inputs are things like school resources, teacher quality, and family attributes, and the outcome is student achievement (Hanushek, 2007). Besides the inputs listed by Hanushek, researchers also give attention to student inputs into the (higher) education production function, in particular: lecture attendance and additional hours of study. There is evidence that lecture attendance is an important determinant of academic achievement in higher education, for example: Schmidt (1983); Romer (1993); Durden and Ellis (1995); Dolton, Marcenaro and Navarro (2003); Martins and Walker (2006) and Cohn and Johnson (2006). There is also evidence that additional study-hours are positively related to grades, for example: Martins and Walker (2006); Arulampalam, Naylor and Smith (2007) and Stinebrickner and Stinebrickner (2007).

Despite the amount of attention given to the empirical relationship between students' educational inputs (lecture attendance and additional study-hours) and their academic achievement, there is a paucity of evidence on the micro-level determinants of these (higher) education inputs. The main contribution of this paper is to use novel measures of individual differences that produce new insights about student inputs into the (higher) education production function. Data from the Irish University Study (IUS) are used; these were collected through a web-survey that the authors designed. The analysis includes the following measures: willingness to take risks, consideration of future consequences and non-cognitive ability traits. Survey measures of these differences are a recent innovation in applied labour economics (Bonin et al., 2007). A recent paper by Borghans, Duckworth, Heckman and ter Weel (2008) suggests that economics can benefit from incorporating the findings of personality psychology to better predict and understand outcomes.

The remainder of the paper is organised as follows. The next section describes the theoretical framework and its empirical implications. The third section presents the measurement of individual differences. The fourth section describes the survey data. The fifth section presents the method and results. The results show that besides age, gender and year of study, the main determinants of lecture attendance and additional study-hours are attitude to risk, future-orientation and consci- 
entiousness. In addition, future-orientation, and in particular conscientiousness, determine lecture attendance to a greater extent than they determine additional study. The results also show that family income and financial transfers (from both parents and the state) do not determine any educational input. This study suggests that non-cognitive abilities may be more important than financial constraints in the determination of educational inputs such as lecture attendance and additional study-hours. Finally, the sixth section concludes with a discussion.

\section{Theoretical Framework and Empirical Implications}

After enrolling in a course of higher education, students allocate their time between educational inputs (primarily lecture attendance and additional study-hours), and other activities, such as leisure and part-time work. The allocation of time has important consequences: theory suggests that students should spend an extra hour on educational input if the marginal benefit exceeds the marginal cost. Benefits occur in the form of higher academic achievement and higher future earnings. ${ }^{1}$ Costs occur in the form of sacrificed leisure or sacrificed consumption (via reduced labour-supply).

In the Juster and Stafford (1991) model of intertemporal time use, each hour spent in today's skill acquisition costs lost wages and lost utility from leisure. However, skill acquisition also raises future wages and produces greater consumption opportunities in the future. The model (Juster and Stafford; 1991) indicates a choice between leisure $\left(t_{1}\right)$, training time $\left(t_{2}\right)$ and market goods expenditures $(X)$. The framework followed in this paper is slightly different: training time is replaced by educational inputs so that there is a choice between leisure $\left(t_{1}\right)$, educational inputs $\left(t_{2}\right)$ and market goods expenditures $(X)$. Market goods are purchased using the proceeds of market work (or labour-supply). The decision problem is to choose between leisure $\left(t_{1}\right)$, educational inputs $\left(t_{2}\right)$ and market goods expenditures $(X)$ in each period in order to maximise the presented value of discounted utility. There are two periods: 'during higher education' and 'after higher education'.

\footnotetext{
${ }^{1}$ The empirical evidence on the relationship between educational inputs and academic achievement was discussed in the previous section. Empirical studies have also established how grades affect future earnings. For evidence on the positive relationship between college grades and subsequent earnings, see Wise (1975), Filer (1983), Jones and Jackson (1990), Loury and Garman (1995), McIntosh (2006) and Naylor, Smith and McKnight (2007).
} 


$$
\sum_{m=0}^{M} U\left(t_{1 m}, X_{m}\right) /(1+r)^{m}
$$

subject to

$$
R_{m}+1=R_{m}+\left(T-t_{1 m}-t_{2 m}\right) \alpha K_{m}-p X_{m}+r R_{m}
$$

and

$$
K_{m+1}=K_{m}+g\left(K_{m}, t_{2 m}\right)-\delta K_{m}
$$

where $T-t_{1}-t_{2}$ is market work time, $M$ is the planning horizon, and financial assets are $R$ with a discount rate of $r$. The stock of human capital, $K$, produces earnings at a rate $\alpha$ and depreciates at the rate $\delta . g$ is the production function for human capital; market goods can be used to produce increments to the stock of human capital. Students discount future earnings, which are determined by academic achievement.

To empiricise this model requires novel data. The authors use data collected through a websurvey that they designed for this purpose. The discount rate in Juster and Stafford (1991) is approximated using survey measures of future-orientation and attitude to risk. Finally, less time may be allocated to educational inputs if students are constrained by their financial situation. In the empirical analysis, the importance of financial constraints is examined using survey measures of financial transfers: from students' parents, and from the state. The inclusion of transfers is an additional consideration to the model presented by Juster and Stafford. In this paper's framework, parental transfers are treated as exogenous to students' schooling and work decisions: as in Oettinger (2005), but in contrast to Kalenkoski (2008). 


\section{Measurement of Individual Differences}

A recent paper by Borghans, Duckworth, Heckman and ter Weel (2008) suggests that economics can benefit from incorporating the findings of personality psychology to better predict and understand outcomes. These findings from personality psychology relate to the importance of individual differences such as attitude to risk, consideration of future consequences and non-cognitive ability traits. Daly, Delaney and Harmon (2009) finds that financial discounting is related to a range of psychological variables including consideration of future consequences, self-control, conscientiousness, extraversion, and experiential avoidance. ${ }^{2}$

Bonin et al. (2007) use a question that asks about willingness to take risks on an 11-point scale, as follows: "Please indicate on a scale of 0-10, how willing you are to take risks in general, where 0 indicates unwilling to take risks and 10 indicates fully prepared to take risks." Bonin et al. (2007) show that this measure is a good predictor of actual risk-taking behaviour. Dohmen et al. (2005) report that a general 'attitude to risk' question, such as that used by Bonin et al. (2007), predicts behaviour across multiple domains, but that a standard lottery measure does not. Jaeger et al. (2010) find that individuals who are more willing to take risks are more likely to migrate between labour markets in Germany.

Strathman et al. (1994) construct a scale to measure individuals' consideration of future consequences (CFC). It contains twelve statements reflecting an individual's tendency to consider the immediate and future consequences of their behaviour. Respondents rate how characteristic each statement is of their own behaviour on a scale from 1 (extremely uncharacteristic) to 5 (extremely characteristic). Strathman et al. (1994) collected data from 7 samples of college students to show that the measure has acceptable reliability and validity. Eikebrokk and Nyhus (2008) is the first validation study of the CFC using panel data from a large representative sample.

The "Big Five" are commonly measured using the 'Ten Item Personality Inventory' (as developed by Gosling et al., 2003). Kyllonen (2008) is perhaps the most detailed assessment of how to measure non-cognitive ability; he associates an array of non-cognitive abilities (shown on the

\footnotetext{
${ }^{2}$ As well as being predicted by heart rate variability and blood pressure.
} 
following page) with the Big Five personality traits. ${ }^{3}$ Kyllonen (2008) makes a clear link between the traits measured by the Big Five, and their association with various non-cognitive abilities.

Table 1: The Big Five Personality Traits (Kyllonen, 2008)

\begin{tabular}{|l|l|}
\hline "Big Five" Trait & Non-Cognitive Abilities \\
\hline Conscientiousness: & $\begin{array}{l}\text { Dependability, Responsibility, Aspiration, } \\
\text { Achievement-striving, Ethics, Integrity, Honesty }\end{array}$ \\
Emotional Stability: & $\begin{array}{l}\text { Resilience (response to feedback; } \\
\text { working under pressure) } \\
\text { "Core self-evaluation" }\end{array}$ \\
& $\begin{array}{l}\text { (self-efficacy, locus of control) } \\
\text { Engagement, Interest, Enthusiasm } \\
\text { Agreeableness: }\end{array}$ \\
Extraversion: & Ability to work with others \\
\end{tabular}

\section{Data}

Wave 2 of the Irish University Study (henceforth IUS Wave 2) is analysed in this paper. The survey was conducted by the UCD Geary Institute during spring 2009. The data were collected through a web-survey that the authors designed. ${ }^{4}$ The survey received 4,770 responses, which equates to a response rate of 20 percent. Summary statistics related to this sample are presented in Table 2 (shown below). In Table 2, outliers for independent variables are adjusted. However, there is no scaling of financial support variables and there is no adjustment for missing values. The analytical sample has 2,867 observations. This figure can be compared with the $N$ column in Table 2. The most missing values arise for the financial support variables: approximately 18 percent of the analytical sample. On average, missing values are present for approximately 10 percent of the analytical sample. Analysis is restricted to observations where students are enrolled in full-time courses; this is because part-time students are a characteristically different group. In addition, the

\footnotetext{
${ }^{3}$ Emotional stability is sometimes referred to as its opposite: neuroticism.

${ }^{4}$ More details are available from the corresponding author, and on the following website: http://sites.google.com/site/ryaneconomics/research.
} 
sample is restricted to full-time undergraduates because post-graduates are also a characteristically different group. All of the students in the analytical sample are studying for bachelor degrees.

Table 2: Summary Statistics: IUS Wave 2

\begin{tabular}{lccc}
\hline \hline \multicolumn{1}{c}{ Variable } & Mean & Std. Dev. & N \\
\hline Student's percentage of lectures attended & 81.25 & 17.76 & 2502 \\
Monthly income from family (inc. exp. paid) & 210.03 & 213.43 & 2339 \\
Monthly income from state (maintenance grant) & 50.40 & 116.33 & 2363 \\
Student's age & 21.10 & 4.20 & 2843 \\
Whether the student is male & 0.36 & 0.48 & 2867 \\
Student's year of course & 2.27 & 1.10 & 2863 \\
Student's willingness to take risks & 6.49 & 1.75 & 2581 \\
Student's future-orientation & 12.30 & 2.44 & 2561 \\
Student's openness & 10.76 & 2.10 & 2581 \\
Student's conscientiousness & 10.26 & 2.61 & 2580 \\
Student's extraversion & 9.20 & 2.74 & 2580 \\
Student's agreeableness & 9.79 & 2.23 & 2580 \\
Student's emotional stability & 6.65 & 2.76 & 2579 \\
\hline
\end{tabular}

Lecture attendance is measured as the self-reported percentage of lectures attended by each student. The distribution of percentage lectures attended is shown in Fig.1 on the following page. Approximately $12 \%$ of students claim to attend all of their lectures. $32 \%$ of students claim to attend $90 \%$ or more of their lectures. $47 \%$ of students claim to attend $80 \%$ or more of their lectures. $57 \%$ of students claim to attend $70 \%$ or more of their lectures. $67 \%$ of students claim to attend $50 \%$ or more of their lectures.

Additional study-hours are measured using the following question: "How many hours per week do you spend on average on personal study time?" Respondents give their answer in a grid comprised of hours (per week), categorised as follows: 0, 1-5, 6-10, 11-15, 16-20, 21-30, 31-40, 41-50, 51-60, 60+. ${ }^{5}$ This is a stylised estimate of time use. According to Kan and Pudney (2007), the survey respondent must perform two tasks when providing a stylised estimate of their time use; these are to: recall activities in the recent past, and carry out an appropriate form of averaging. A categorical plot (Fig.2) shows the frequency of students reporting their additional study time in each category. Missing values are not re-coded for either dependent variable (lecture attendance or

\footnotetext{
${ }^{5}$ Additional study-hours are elicited on average per week. However, the authors are aware that survey respondents may frame their answers around the week of the survey, rather than the average week. To control for this, we include a variable indicating the week that the survey was completed. There is an additional concern though, that students filling out the survey in later weeks are characteristically different to students who fill out the survey earlier.
} 
additional study). ${ }^{6}$

Fig.1: Percentage of Lectures Attended: Irish Universities Study

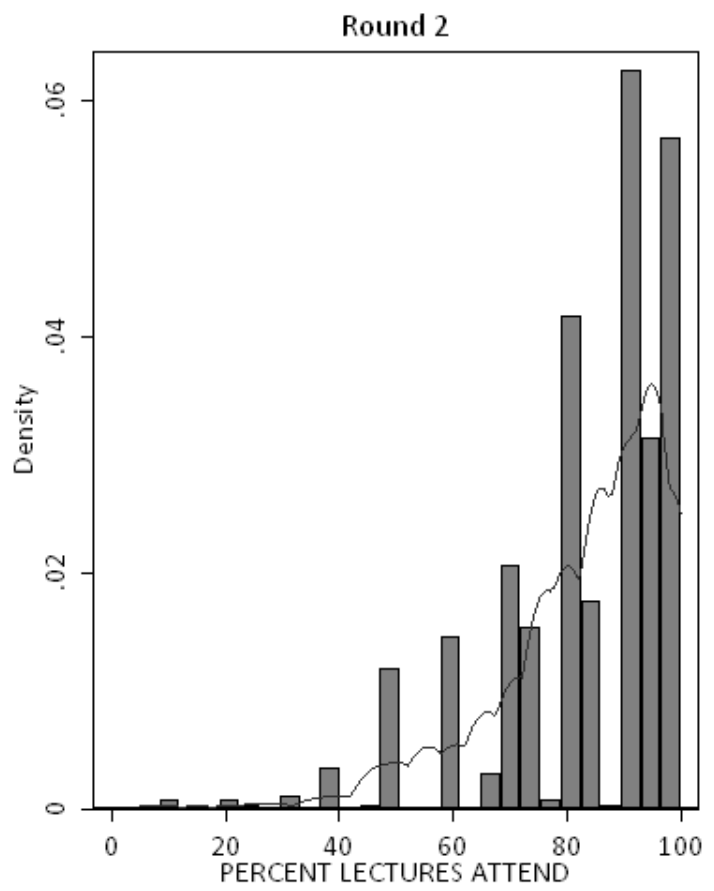

The independent variables are grouped into four themes: (i) financial transfers (ii) social background (iii) individual differences, and (iv) fixed effects (based on controlling for university). Financial supports include finance received from students' parents, and finance received from the state. Finance received from students' parents is the sum of direct transfers and indirect payments on the behalf of students. ${ }^{7}$ The social background variables are as follows: student's age, student's gender (whether the student is male), whether the student's father has some higher education,

\footnotetext{
${ }^{6}$ Though in recent years methods for dealing with missing data in the dependent variable have been developed (Williams, 2008). A couple of observations for each dependent variable have been set to missing values as they were very extreme.

${ }^{7}$ Finance received from the state is known in Ireland as the "higher education maintenance grant"; it comes with fee-remission, which was very salient when tuition fees were charged in Ireland prior to 1997. However, there remains an annual "registration fee" for Irish students (currently $€ 1,500$ ), which is covered by the remission. The "grant", as it is colloquially known, is never more than 3,342 and is often closer to $€ 1,370$, depending on how far the student lives away from college. To qualify for the full grant, the (pre-tax) family income of the student must be no more than $€ 41,110$ (if the family has four or fewer children.) There are slightly higher thresholds for larger numbers of children. In addition, reduced grant payments are available up to a family income threshold of $€ 51,380$. However, in the band below this upper threshold (that is, €51,380), only the students' registration fee is paid. The most recent figure for the average industrial wage in Ireland is from 2006: $€ 29,910.92$
} 
whether the student's father has a professional or lower professional occupation, and the family income of the student. ${ }^{8}$ The year of the course that the student is studying in is also controlled for. This is important because students in later years may have developed study habits. The concepts related to variables measuring individual differences were discussed in detail in Section 3.

Fig.2: Additional Study-Hours: Irish Universities Study

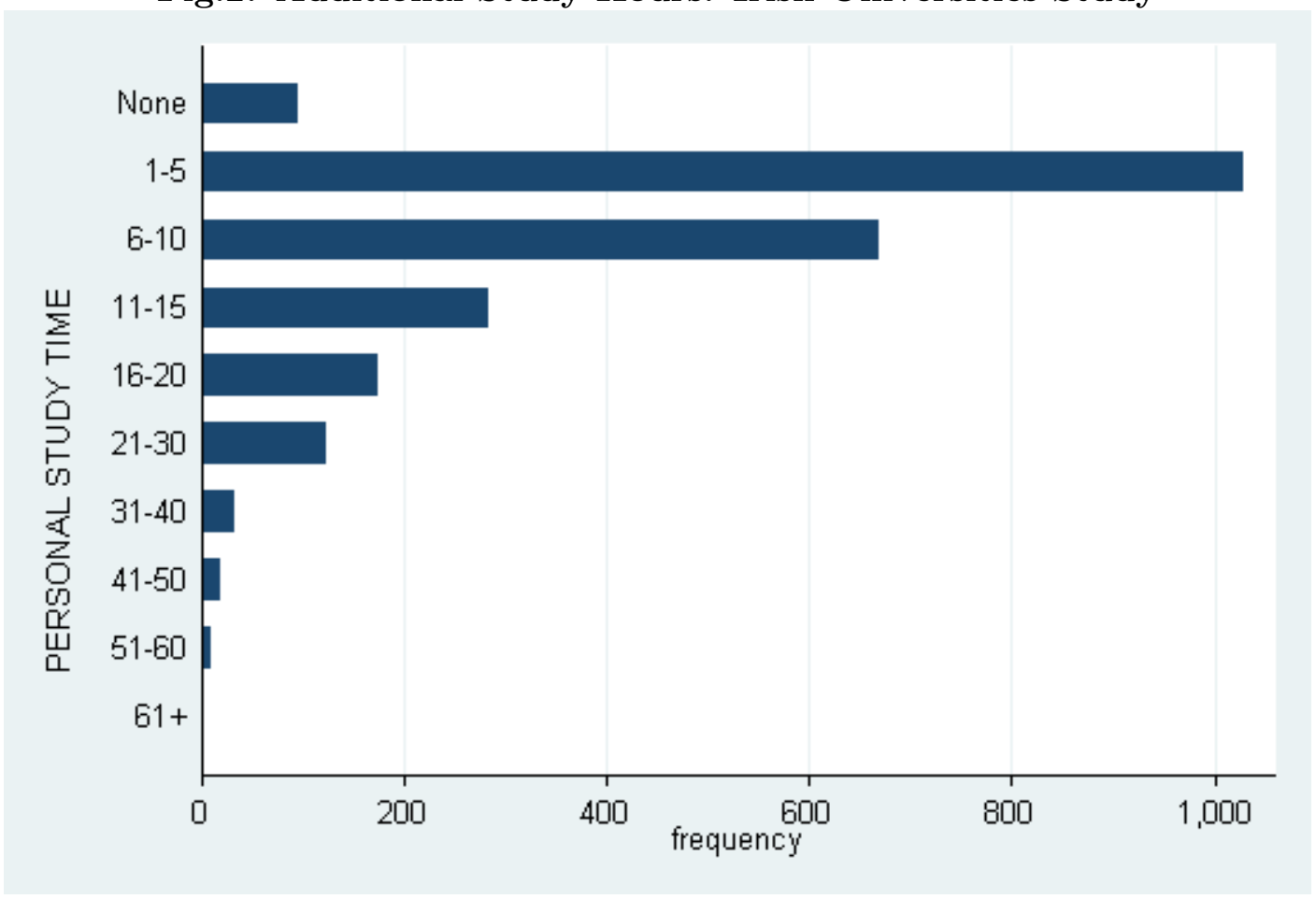

The sampling strategy was based on the Irish university population for the academic year 2006/07 (the most recent year that figures were available). ${ }^{9} \quad 16,000$ undergraduates and 8,000 postgraduates were contacted using their institutional email address. Each university was informed by the authors about the need for a sample of a certain size (based on the size of each university population). Given the requirement for a sample of a certain size, each university randomly selected the corresponding number of individuals from their administrative records. ${ }^{10}$ The university

\footnotetext{
${ }^{8}$ The family income variable is top-coded at $€ 200,000+$. The uppermost category accounts for 3.43 percent of the sample.

9 Information about the population of university students in Ireland is taken from the HEA website: http://www.hea.ie/en/statistics

${ }^{10}$ This was done by randomly generating a unique decimal number between 0 and 1 for every undergraduate and postgraduate student. Those who had the lowest random numbers made up the undergradaute and postgraduate samples.
} 
subsequently contacted those individuals using students' institutional email addresses.

Outliers are re-coded to be missing values (for independent variables only); then all missing values are re-coded to be zero (the dummy variable adjustment approach). Multiple imputation and complete case analysis are used as sensitivity-tests. The approach for treating outliers in the independent variables is based on trimming: all values above the 95th percentile are set equal to missing values if they are extreme. It is also important to note the sequence of how missing values and outliers are addressed: outliers are dealt with first; this preserves the most information.

Finally, some comparisons can be made between the sample and the population of university students in Ireland (during 2006/07). During the academic year 2006/07, there were 68,039 full-time undergraduates in the seven Irish universities (and their affiliated colleges). $64 \%$ of the sample are female compared to $59 \%$ of the population. $12 \%$ of the sample are aged 18 compared to $11 \%$ of the population. $23 \%$ of the sample are aged 19 compared to $17 \%$ of the population. $21 \%$ of the sample are aged 20 compared to $18 \%$ of the population. $20 \%$ of the sample are aged 21 compared to $15 \%$ of the population. $10 \%$ of the sample are aged 22 compared to $9 \%$ of the population. ${ }^{11}$ Overall, on observable demographics, the IUS Wave 2 sample is broadly representative of its corresponding population.

\section{Method and Results}

The determinants of lecture attendance and additional study are estimated using the following econometric model:

$$
Y_{i}=\alpha_{i}+T_{i} \beta+S_{i} \gamma+D_{i} \delta+I_{i} \zeta+\mu_{i}
$$

where $Y_{i}$ is lecture attendance or additional study; $T_{i}$ is a matrix of financial transfer variables; $S_{i}$ is a matrix of social background variables; $D_{i}$ is a matrix of individual differences; and $I_{i}$ is a matrix representing institutional fixed effects. Lecture attendance is modelled using ordinary

\footnotetext{
${ }^{11}$ Unfortunately, it was not possible to access figures that did not include postgraduates for the population age figures.
} 
least squares (OLS) regression. As hours of additional study are measured in time-use categories, additional study-hours are modelled using interval regression, following Stewart (1983). ${ }^{12}$ The models of lecture attendance and additional study-hours are estimated separately for students enrolled in courses related to science, engineering, technology and maths (STEM); and non-STEM subjects. This distinction is important because STEM students are required to attend more lectures than non-STEM students. STEM students also have less time for additional study, compared to non-STEM students. ${ }^{13}$

Table 3 shows results relating to the determinants of lecture attendance, estimated using OLS regression. The first four columns build up the model through the following stages: a set of variables measuring financial transfer variables, a set of variables measuring social background variables, a set of variables measuring individual differences; and a set of variables representing institutional fixed effects. The fifth column relates to STEM students only. The sixth column only relates to non-STEM students.

The results in Table 3 show that the higher a student's age the more likely the student is to attend lectures; unless they are studying in a STEM subject area. Male students are less likely to attend their lectures. The presence of some higher education in the father's background predicts more lecture attendance if: (i) the student is studying in a STEM subject area; (ii) there are controls for non-cognitive ability traits but no controls for institutional fixed effects.

Also in Table 3, higher levels of family income predict less lecture attendance for students in a STEM subject area. The presence of a professional (or lower professional) qualification in the father's background predicts less lecture attendance if the student is not in a STEM subject area. Students with a higher level of willingness to take risks are less likely to attend lectures, unless they are in a STEM subject area. Students with higher levels of future-orientation and conscientiousness are more likely to attend their lectures.

Table 4 shows results relating to the determinants of additional study-hours, estimated using interval regression. It follows the same format as Table 3. The results in Table 4 show that

\footnotetext{
${ }^{12} \mathrm{An}$ interval (or grouped) variable is similar to an ordinal variable, except that the intervals between the values of the grouped variable are (usually) equally spaced; and the threshold values are known.

${ }^{13}$ Each model includes missing value (and outlier) adjustment. All of the financial transfer variables are divided by 1,000 . This applies to "parental transfers" and "income from state aid" (i.e. the grant). Where they apply, control variables for missing value adjustment and institutional fixed effects are not shown in the results (Tables 3 and 4 ). Outliers and missing values are adjusted only for independent variables.
} 
the higher a student's age the more likely the student is to do additional hours of study. Male students are more likely to do additional hours of study, but only if they are in a STEM subject area. Students in a later year of their studies are more likely to do additional hours of study. Finally, students with higher levels of future-orientation and conscientiousness are more likely to do additional hours of study.

In summary, the higher a student's age the more likely they are to attend their lectures and the more likely they are to do additional hours of study. Male students are less likely to attend their lectures but they are more likely to do additional hours of study in the STEM subject area. Students in a later year of their studies are more likely to do additional hours of study. Students with a higher level of willingness to take risks are less likely to attend their lectures, but are no different to other students in relation to additional hours of study. Students with higher levels of future-orientation and conscientiousness are more likely to attend their lectures, and they are more likely to do additional hours of study.

Besides age, gender and year of study, the main determinants of lecture attendance and additional study-hours are attitude to risk, future-orientation and conscientiousness. Finally, futureorientation, and in particular conscientiousness, determine lecture attendance to a greater extent than they determine additional study. The results also show that financial transfers (from both parents and the state) and family income do not determine any educational input. While causal identification of the effects of specific types of transfers require further study, our results suggest that non-cognitive abilities may be more important than financial constraints in the determination of educational inputs such as lecture attendance and additional study-hours. 
Table 3: Percentage of Lectures Attended: OLS Regression

\begin{tabular}{|c|c|c|c|c|c|c|}
\hline & $\begin{array}{c}(1) \\
\text { Transfers }\end{array}$ & $\begin{array}{c}(2) \\
\text { Social }\end{array}$ & $\begin{array}{c}(3) \\
\text { Non-Cog }\end{array}$ & $\begin{array}{l}\text { (4) } \\
\text { FE }\end{array}$ & $\begin{array}{c}(5) \\
\text { STEM }\end{array}$ & $\begin{array}{c}(6) \\
\text { Non-STEM }\end{array}$ \\
\hline Log (Monthly income from family) & $\begin{array}{r}-206.318 \\
(166.447)\end{array}$ & $\begin{array}{c}181.138 \\
(173.355)\end{array}$ & $\begin{array}{c}201.725 \\
(164.689)\end{array}$ & $\begin{array}{c}202.471 \\
(163.888)\end{array}$ & $\begin{array}{c}153.161 \\
(309.881)\end{array}$ & $\begin{array}{c}264.943 \\
(194.281)\end{array}$ \\
\hline Log (Monthly income from the state) & $\begin{array}{c}60.738 \\
(180.059)\end{array}$ & $\begin{array}{c}-47.529 \\
(189.177)\end{array}$ & $\begin{array}{c}2.859 \\
(179.285)\end{array}$ & $\begin{array}{c}70.877 \\
(178.431)\end{array}$ & $\begin{array}{c}-84.591 \\
(344.914)\end{array}$ & $\begin{array}{c}110.809 \\
(209.558)\end{array}$ \\
\hline Students' age & & $\begin{array}{c}0.574^{* * *} \\
(0.092)\end{array}$ & $\begin{array}{c}0.512^{* * *} \\
(0.088)\end{array}$ & $\begin{array}{c}0.491^{* * *} \\
(0.088)\end{array}$ & $\begin{array}{c}0.306 \\
(0.252)\end{array}$ & $\begin{array}{c}0.540^{* * *} \\
(0.095)\end{array}$ \\
\hline Whether the student is male & & $\begin{array}{c}-4.253^{* * *} \\
(0.733)\end{array}$ & $\begin{array}{c}-3.220^{* * *} \\
(0.742)\end{array}$ & $\begin{array}{c}-3.122^{* * *} \\
(0.739)\end{array}$ & $\begin{array}{c}-3.155^{* *} \\
(1.384)\end{array}$ & $\begin{array}{c}-3.207^{* * *} \\
(0.902)\end{array}$ \\
\hline Whether the father has some higher education & & $\begin{array}{c}0.904 \\
(0.824)\end{array}$ & $\begin{array}{l}1.338^{*} \\
(0.783)\end{array}$ & $\begin{array}{c}1.198 \\
(0.783)\end{array}$ & $\begin{array}{c}3.490^{* *} \\
(1.484)\end{array}$ & $\begin{array}{c}0.325 \\
(0.932)\end{array}$ \\
\hline Family income in brackets of $€ 20,000$ & & $\begin{array}{l}-0.197 \\
(0.173)\end{array}$ & $\begin{array}{l}-0.153 \\
(0.165)\end{array}$ & $\begin{array}{l}-0.150 \\
(0.165)\end{array}$ & $\begin{array}{c}-0.743^{* *} \\
(0.352)\end{array}$ & $\begin{array}{c}0.027 \\
(0.188)\end{array}$ \\
\hline Whether the father is a prof./lower prof. & & $\begin{array}{l}-1.077 \\
(0.826)\end{array}$ & $\begin{array}{l}-0.829 \\
(0.784)\end{array}$ & $\begin{array}{l}-1.188 \\
(0.782)\end{array}$ & $\begin{array}{c}0.619 \\
(1.453)\end{array}$ & $\begin{array}{c}-1.956^{* *} \\
(0.933)\end{array}$ \\
\hline Student's year of course & & $\begin{array}{c}0.009 \\
(0.328)\end{array}$ & $\begin{array}{l}-0.264 \\
(0.312)\end{array}$ & $\begin{array}{l}-0.323 \\
(0.311)\end{array}$ & $\begin{array}{c}0.266 \\
(0.615)\end{array}$ & $\begin{array}{l}-0.575 \\
(0.371)\end{array}$ \\
\hline The week the survey was conducted & & $\begin{array}{c}-1.428^{* * *} \\
(0.349)\end{array}$ & $\begin{array}{c}-1.119^{* * *} \\
(0.331)\end{array}$ & $\begin{array}{c}-1.219^{* * *} \\
(0.350)\end{array}$ & $\begin{array}{l}-0.988 \\
(0.672)\end{array}$ & $\begin{array}{c}-1.342^{* * *} \\
(0.415)\end{array}$ \\
\hline Student's willingness to take risks & & & $\begin{array}{c}-0.519^{* *} \\
(0.218)\end{array}$ & $\begin{array}{c}-0.506^{* *} \\
(0.217)\end{array}$ & $\begin{array}{c}0.061 \\
(0.398)\end{array}$ & $\begin{array}{c}-0.760 * * * \\
(0.262)\end{array}$ \\
\hline Student's future-orientation & & & $\begin{array}{c}0.630^{* * *} \\
(0.144)\end{array}$ & $\begin{array}{c}0.600 * * * \\
(0.144)\end{array}$ & $\begin{array}{c}0.748^{* * *} \\
(0.274)\end{array}$ & $\begin{array}{c}0.574^{* * *} \\
(0.170)\end{array}$ \\
\hline Student's openness & & & $\begin{array}{l}-0.233 \\
(0.179)\end{array}$ & $\begin{array}{c}-0.278 \\
(0.178)\end{array}$ & $\begin{array}{c}-0.852^{* *} \\
(0.350)\end{array}$ & $\begin{array}{l}-0.095 \\
(0.209)\end{array}$ \\
\hline Student's conscientiousness & & & $\begin{array}{c}1.871^{* * *} \\
(0.136)\end{array}$ & $\begin{array}{c}1.884^{* * *} \\
(0.136)\end{array}$ & $\begin{array}{c}1.986^{* * *} \\
(0.252)\end{array}$ & $\begin{array}{c}1.829 * * * \\
(0.162)\end{array}$ \\
\hline Student's extraversion & & & $\begin{array}{l}-0.179 \\
(0.134)\end{array}$ & $\begin{array}{l}-0.187 \\
(0.133)\end{array}$ & $\begin{array}{c}-0.382 \\
(0.263)\end{array}$ & $\begin{array}{c}-0.056 \\
(0.156)\end{array}$ \\
\hline Student's agreeableness & & & $\begin{array}{c}0.235 \\
(0.157)\end{array}$ & $\begin{array}{c}0.228 \\
(0.156)\end{array}$ & $\begin{array}{c}0.190 \\
(0.311)\end{array}$ & $\begin{array}{c}0.217 \\
(0.182)\end{array}$ \\
\hline Student's emotional stability & & & $\begin{array}{c}0.170 \\
(0.131)\end{array}$ & $\begin{array}{c}0.167 \\
(0.130)\end{array}$ & $\begin{array}{c}0.059 \\
(0.247)\end{array}$ & $\begin{array}{c}0.198 \\
(0.154)\end{array}$ \\
\hline Constant & $\begin{array}{c}81.804^{* * *} \\
(0.861)\end{array}$ & $\begin{array}{c}75.391^{* * *} \\
(2.564)\end{array}$ & $\begin{array}{c}52.509 * * * \\
(4.084)\end{array}$ & $\begin{array}{c}55.604^{* * *} \\
(4.295)\end{array}$ & $\begin{array}{c}60.573^{* * *} \\
(8.477)\end{array}$ & $\begin{array}{c}54.808^{* * *} \\
(5.086)\end{array}$ \\
\hline Observations & 2502 & 2502 & 2502 & 2502 & 705 & 1797 \\
\hline R-squared & 0.003 & 0.046 & 0.148 & 0.162 & 0.175 & 0.171 \\
\hline
\end{tabular}

Note: The first column (Transfers) uses financial transfers only. The second column (Social) estimates the same model but adds social background variables. The third column (Non-Cog) adds measures of individual differences. The fourth column $(F E)$ adds institutional fixed effects. The fifth column (STEM) runs the estimation from the fourth column for STEM students only. The sixth column (Non-STEM) runs the estimation from the fourth column for non-STEM students only. Monthly income from family includes expenditures covered on behalf of students by their family. Monthly income from the state refers to the higher education maintenance grant in the Republic of Ireland. Whether the father is a prof./lower prof. refers to whether the father is a professional/lower professional. All of the financial transfer variables are divided by 1,000. This applies to "monthly income from family" and "monthly income from the state" (i.e. the grant). Where they apply, control variables for missing value adjustment and institutional fixed effects are not shown in the results. Outliers and missing values are adjusted only for independent variables. 
Table 4: Determinants of Additional Study-Hours: Interval Regression

\begin{tabular}{|c|c|c|c|c|c|c|}
\hline & $\begin{array}{c}(1) \\
\text { Transfers }\end{array}$ & $\begin{array}{c}(2) \\
\text { Social }\end{array}$ & $\begin{array}{c}(3) \\
\text { Non-Cog }\end{array}$ & $\begin{array}{l}(4) \\
\mathrm{FE}\end{array}$ & $\begin{array}{c}(5) \\
\text { STEM }\end{array}$ & $\begin{array}{c}(6) \\
\text { Non-STEM }\end{array}$ \\
\hline Log (Monthly income from family) & $\begin{array}{c}-192.879^{* *} \\
(87.920)\end{array}$ & $\begin{array}{c}-4.535 \\
(89.118)\end{array}$ & $\begin{array}{c}-6.409 \\
(87.209)\end{array}$ & $\begin{array}{c}-5.899 \\
(86.976)\end{array}$ & $\begin{array}{c}71.506 \\
(153.533)\end{array}$ & $\begin{array}{c}-24.783 \\
(104.959)\end{array}$ \\
\hline Log (Monthly income from state) & $\begin{array}{l}-50.253 \\
(94.690)\end{array}$ & $\begin{array}{l}-23.891 \\
(96.835)\end{array}$ & $\begin{array}{l}-26.941 \\
(94.560)\end{array}$ & $\begin{array}{c}-6.281 \\
(94.343)\end{array}$ & $\begin{array}{c}99.370 \\
(170.460)\end{array}$ & $\begin{array}{c}-48.504 \\
(112.644)\end{array}$ \\
\hline Student's age & & $\begin{array}{c}0.386^{* * *} \\
(0.047)\end{array}$ & $\begin{array}{c}0.343^{* * *} \\
(0.046)\end{array}$ & $\begin{array}{c}0.343^{* * *} \\
(0.046)\end{array}$ & $\begin{array}{c}0.355^{* * *} \\
(0.125)\end{array}$ & $\begin{array}{c}0.328^{* * *} \\
(0.051)\end{array}$ \\
\hline Whether the student is male & & $\begin{array}{l}-0.186 \\
(0.376)\end{array}$ & $\begin{array}{c}0.350 \\
(0.393)\end{array}$ & $\begin{array}{c}0.431 \\
(0.393)\end{array}$ & $\begin{array}{c}1.644^{* *} \\
(0.689)\end{array}$ & $\begin{array}{l}-0.027 \\
(0.487)\end{array}$ \\
\hline Whether the father has some higher education & & $\begin{array}{c}0.557 \\
(0.424)\end{array}$ & $\begin{array}{c}0.592 \\
(0.415)\end{array}$ & $\begin{array}{c}0.431 \\
(0.415)\end{array}$ & $\begin{array}{l}-0.733 \\
(0.732)\end{array}$ & $\begin{array}{c}0.817 \\
(0.503)\end{array}$ \\
\hline Family income in brackets of $€ 20,000$ & & $\begin{array}{c}0.068 \\
(0.089)\end{array}$ & $\begin{array}{c}0.056 \\
(0.088)\end{array}$ & $\begin{array}{c}0.017 \\
(0.088)\end{array}$ & $\begin{array}{c}0.069 \\
(0.172)\end{array}$ & $\begin{array}{c}0.011 \\
(0.102)\end{array}$ \\
\hline Whether the father is a prof./lower prof. & & $\begin{array}{l}-0.170 \\
(0.425)\end{array}$ & $\begin{array}{l}-0.041 \\
(0.415)\end{array}$ & $\begin{array}{l}-0.171 \\
(0.415)\end{array}$ & $\begin{array}{c}0.605 \\
(0.723)\end{array}$ & $\begin{array}{l}-0.469 \\
(0.503)\end{array}$ \\
\hline Student's year of course & & $\begin{array}{c}1.617^{* * *} \\
(0.169)\end{array}$ & $\begin{array}{c}1.550^{* * * *} \\
(0.165)\end{array}$ & $\begin{array}{c}1.564^{* * *} \\
(0.165)\end{array}$ & $\begin{array}{c}1.717^{* * *} \\
(0.309)\end{array}$ & $\begin{array}{c}1.579^{* * *} \\
(0.199)\end{array}$ \\
\hline The week the survey was conducted & & $\begin{array}{l}-0.259 \\
(0.181)\end{array}$ & $\begin{array}{l}-0.183 \\
(0.177)\end{array}$ & $\begin{array}{l}-0.223 \\
(0.187)\end{array}$ & $\begin{array}{l}-0.278 \\
(0.334)\end{array}$ & $\begin{array}{l}-0.179 \\
(0.226)\end{array}$ \\
\hline Student's willingness to take risks & & & $\begin{array}{l}-0.126 \\
(0.115)\end{array}$ & $\begin{array}{l}-0.114 \\
(0.114)\end{array}$ & $\begin{array}{c}0.090 \\
(0.196)\end{array}$ & $\begin{array}{l}-0.178 \\
(0.141)\end{array}$ \\
\hline Student's future-orientation & & & $\begin{array}{c}0.462^{* * *} \\
(0.076)\end{array}$ & $\begin{array}{c}0.443^{* * *} \\
(0.076)\end{array}$ & $\begin{array}{c}0.531^{* * *} \\
(0.136)\end{array}$ & $\begin{array}{c}0.402^{* * *} \\
(0.092)\end{array}$ \\
\hline Student's openness & & & $\begin{array}{l}0.184^{*} \\
(0.095)\end{array}$ & $\begin{array}{c}0.190^{* *} \\
(0.095)\end{array}$ & $\begin{array}{l}0.290^{*} \\
(0.174)\end{array}$ & $\begin{array}{c}0.153 \\
(0.113)\end{array}$ \\
\hline Student's conscientiousness & & & $\begin{array}{c}0.453^{* * * *} \\
(0.072)\end{array}$ & $\begin{array}{c}0.461^{* * * *} \\
(0.071)\end{array}$ & $\begin{array}{c}0.344^{* * *} \\
(0.124)\end{array}$ & $\begin{array}{c}0.518^{* * *} \\
(0.087)\end{array}$ \\
\hline Student's extraversion & & & $\begin{array}{c}0.024 \\
(0.071)\end{array}$ & $\begin{array}{c}0.023 \\
(0.071)\end{array}$ & $\begin{array}{l}-0.117 \\
(0.131)\end{array}$ & $\begin{array}{c}0.060 \\
(0.084)\end{array}$ \\
\hline Student's agreeableness & & & $\begin{array}{c}0.078 \\
(0.083)\end{array}$ & $\begin{array}{c}0.079 \\
(0.083)\end{array}$ & $\begin{array}{c}0.140 \\
(0.154)\end{array}$ & $\begin{array}{c}0.051 \\
(0.098)\end{array}$ \\
\hline Student's emotional stability & & & $\begin{array}{c}0.162^{* *} \\
(0.069)\end{array}$ & $\begin{array}{c}0.156^{* *} \\
(0.069)\end{array}$ & $\begin{array}{c}0.137 \\
(0.123)\end{array}$ & $\begin{array}{l}0.161^{*} \\
(0.083)\end{array}$ \\
\hline Constant & $\begin{array}{c}14.574^{* * * *} \\
(0.455)\end{array}$ & $\begin{array}{l}2.453^{*} \\
(1.312)\end{array}$ & $\begin{array}{c}-10.500^{* * *} \\
(2.154)\end{array}$ & $\begin{array}{c}-11.418^{* * *} \\
(2.277)\end{array}$ & $\begin{array}{c}-15.767^{* * *} \\
(4.306)\end{array}$ & $\begin{array}{c}-10.922^{* * *} \\
(2.629)\end{array}$ \\
\hline Observations & 2435 & 2435 & 2435 & 2435 & 690 & 1745 \\
\hline R-squared & . & . & . & . & . & . \\
\hline
\end{tabular}

Note: The first column (Transfers) uses financial transfers only. The second column (Social) estimates the same model but adds social background variables. The third column (Non-Cog) adds measures of individual differences. The fourth column $(F E)$ adds institutional fixed effects. The fifth column (STEM) runs the estimation from the fourth column for STEM students only. The sixth column (Non-STEM) runs the estimation from the fourth column for non-STEM students only. Monthly income from family includes expenditures covered on behalf of students by their family. Monthly income from the state refers to the higher education maintenance grant in the Republic of Ireland. Whether the father is a prof./lower prof. refers to whether the father is a professional/lower professional. All of the financial transfer variables are divided by 1,000. This applies to "monthly income from family" and "monthly income from the state" (i.e. the grant). Where they apply, control variables for missing value adjustment and institutional fixed effects are not shown in the results. Outliers and missing values are adjusted only for independent variables. 


\section{Conclusion}

The key results from this paper show that the issues that motivate students to engage with the study process are somewhat broader then the current economics literature might suggest. In particular we find that key personality measures, such as higher levels of future-orientation and conscientiousness, are important determinants of lecture attendance and study time (measured as hours of study) - in fact the impact of these measures on the outcomes are often more significant than other variables such as course or institutional choice, or parental background.

Specifically, we see this work as a natural extension of recent research findings by Heckman which examines how non-cognitive abilities compare with short-term credit constraints in the determination of (higher) educational attainment - Heckman (2000) makes a strong case for the importance of parental environments over the long-run, while Carneiro and Heckman (2002) offers evidence that long-term factors such as the fostering of cognitive and non-cognitive abilities are more important than short-term credit constraints in the determination of post-secondary schooling attainment. The results from this paper extend these findings into the production function for educational outcomes and suggests that non-cognitive abilities may be more important than financial constraints in the determination of higher education inputs such as lecture attendance and additional study-hours.

A number of findings are key for institutional policy setting in higher education. For example, students in a later year of their course are more likely to do additional hours of study, after controlling for a range of other factors including student's age and students' non-cognitive ability traits. This behaviour could be a response by students to the "end-loading" of course credits towards their final and penultimate years of study. This could be an important issue for the setting of institutional policy - the incentives in some Irish universities have changed in recent years as more weighting has been applied to penultimate years of study, however the majority of courses are still heavily weighted towards the final year of study. Any incentives that discourage students from "smoothing" their academic engagement over the entire course of their studies could be viewed as sub-optimal. It may be preferable to allocate an equal weight to each year of study, in relation to 
what determines students' final mark.

Future research should examine the impact of educational inputs (lecture attendance and additional study-hours) on academic achievement in higher education, accounting for the individual differences that the authors have measured (and demonstrated to be important) in this paper. Students' attitude to risk, future-orientation and conscientiousness predict lecture attendance and additional study-hours; whereas financial transfers, family income and father's education do not. This suggests that empirical models of (higher) education production functions may be biased if they do not include measures of non-cognitive ability and other individual differences. Our current research is examining the relationship between students' lecture attendance and their grades, controlling for additional study-hours and non-cognitive ability traits. Moreover, there is still a case for the importance of financial constraints in relation to student welfare. While financial constraints may not stop students attending lectures and doing additional study-hours, there may be other costs that the authors have not observed in this paper.

\section{References}

Arulampalam, W., Naylor, R. and Smith, J. "Am I Missing Something? The Effects of Absence from Class on Student Performance." IZA Discussion Papers 3749, 2008, Institute for the Study of Labor (IZA).

Bonin, H., Dohmen, T., Falk, A., Huffman, D. and Sunde, U. "Cross-sectional Earnings Risk and Occupational Sorting: The Role of Risk Attitudes." Labour Economics, 2007, 14(6), pp. 926-937.

Borghans, L., Duckworth, A. Heckman, J.J. and ter Weel, B. "The Economics and Psychology of Personality Traits." Journal of Human Resources, 2008, 43 (4).

Carneiro, P, and Heckman, J. (2002). The Evidence on Credit Constraints in Postsecondary Schooling. Economic Journal 112(482): 705-734.

Dohmen, T. Falk, A., Huffman, D., Sunde, U., Schupp J. and Wagner, G.G. "Individual Risk Attitudes: New Evidence from a Large, Representative, Experimentally-Validated Survey.” IZA Discussion Paper No. 1730, 2005.

Durden, E. and Ellis, L. "The Effects of Attendance on Student Learning in Principles of Economics". American Economic Review, Vol. 85, No. 2, Papers and Proceedings of the Hundredth and Seventh Annual Meeting of the American Economic Association Washington, DC, January 6-8, 1995 (May, 1995), pp. 343-346.

Dolton, P., Marcenaro, O. and Navarro, L. "The Effective Use of Student Time: A Stochastic Frontier Production Function Case Study." Economics of Education Review, 2003, 22(6), pp. 547-60. 
Eikebrokk, T. and Nyhus, E. "The Consideration Of Future Consequences Scale: An Assessment And Review." University of Agder Working Paper, 2008.

Gosling, S., Rentfrow, P. and Swann Jr., W. "A very brief measure of the Big-Five personality domains." Journal of Research in Personality, 2003, 37, pp. 504-528.

Hanushek, E. "Educational Production Functions." Palgrave Encyclopedia, January 2007.

Heckman, J. (2000). Policies to Foster Human Capital. Research in Economics 54 (1): 3-56.

Jaeger, D., Dohmen, T., Falk, A., Huffman, D. Sunde, W. and Bonin, H. "Direct Evidence on Risk Attitudes and Migration." The Review of Economics and Statistics, August 2010, Vol. 92, No. 3, Pages 684-689.

Joireman, J., Balliet, D., Sprott, D., Spangenberg, E., and Shultz, J. (2008). "Consideration of future consequences, ego-depletion, and self-control: Support for distinguishing between CFC-immediate and CFC-future sub-scales." Personality and Individual Differences, 45, 15-21.

Juster, F.T. and Stafford, F.P. (1991). "The Allocation of Time: Empirical Findings, Behavioral Models, and Problems of Measurement." Journal of Economic Literature, 29, pp. 471-522.

Kalenkoski, C.M., and Pabilonia, S.W. "Parental Transfers, Student Achievement, and the Labour Supply of College Students." US Bureau of Labour Statistics (BLS) Working Papers, 2008, 401.

Kyllonen, C. "Enhancing Noncognitive Skills to Boost Academic Achievement. Educational Testing in America: State Assessments, Achievement Gaps, National Policy and Innovations. Princeton Educational Testing Service, 2008.

Martins, P. and Walker, I. "Student Achievement and University Classes: Effects of Attendance, Size, Peers, and Teachers." IZA Discussion Papers 2490, 2006, Institute for the Study of Labor (IZA).

Oettinger, G. "Parents' Financial Support, Students' Employment, and Academic Performance in College." University of Texas Working Paper, 2005.

Romer, D. "Do Students Go to Class? Should They?" The Journal of Economic Perspectives, 1993, 7(3), pp. 167-74.

Schmidt, R. "Who Maximizes What? A Study in Student Time Allocation". The American Economic Review, 73 (2), Papers and Proceedings of the Ninety-Fifth Annual Meeting of the American Economic Association (May, 1983), pp. 23-28.

Stinebrickner, R. and Stinebrickner, T. R. "The Causal Effect of Studying on Academic Performance." Journal of Labour Economics, 2007.

Strathman, A., Gleicher, F., Boninger D. and Edwards, C. "The consideration of future consequences: weighing immediate and distant outcomes of behavior." Journal of Personality and Social Psychology, 1994, 66 (4), pp. 742752 . 